\title{
ШЛЯХИ ЗНИЖЕННЯ ПЕРИНАТАЛЬНОЇ СМЕРТНОСТІ ТА ЗАХВОРЮВАНОСТІ ПРИ ІНФЕКЦЙНО-ЗАПАЛЬНИХ УРАЖЕННЯХ ПЛОДА
}

\author{
Лазуренко В. В., Пасієшвілі Н. М.
}

\section{ВСТУП}

Проблема інфекційно-запального ураження плода (далі - ІЗУП), яка зумовлена високим рівнем вірусної та бактерійної захворюваності вагітних та призводить до ушкоджень плода і новонародженого, $є$ однією із провідних проблем сучасного акушерства і перинатології. За науковими даними частота внутрішньоутробного інфікування плода становить від 25 до $37 \%$ і не має тенденції до зниження. У структурі неонатальної смертності інфекційна патологія дорівнює, за даними різних авторів, 10-45\% перинатальних втрат ${ }^{1,2,3}$.

Актуальність проблеми пов'язана 3 труднощами своєчасної діагностики, профілактики й лікування. Ризик розвитку ІЗУП залежить від використання щодо вагітних нераціональної антибактеріальної терапії, інвазивних способів дослідження плода, наявності генітальних інфекцій, екстрагенітальної патології, стресових ситуацій. ІЗУП призводить до недоношування вагітності, затримки росту плода, плацентарної дисфункції, підвищуючи показники захворюваності та смертності новонароджених ${ }^{4,5}$. Серед етіологічних причин передчасних пологів відмічається зсув акцентів у бік домінування інфекційних та імунологічних факторів ${ }^{6}$. Частота

Абрамченко В.В., Костючек Д.Ф., Хаджаева Э.Д. Гнойно-септическая инфекция в акушерстве и гинекологии. СПб.: Спец.Лит, 2005. 459 с.

2 Запорожан В.М., Аряєв М.Л., Добрянський Д.О. Акушерство та гінекологія: у 4 т. : національний підручник. Київ : «ВСВ «Медицина», 2013. Т. 2: Неонатологія. C. 636-735.

${ }^{3}$ Picone S. Infection in late preterm infants / S. Picone et al. Early Hum. Dev. 2014. Vol. 90 (1). P. 71-74.

4 Анализ причин антенатальной гибели : материалы 13-го Всероссийского научного форума «Мать и дитя» 25-28 сентября 2012 г. / С.М. Насищева и др. Москва, 2012. С. 119-121.

${ }^{5}$ Агаркова И.М. Неразвивающаяся беременность: оценка факторов риска и прогнозирование. Медицинский альманах. 2010. № 4. С. 82-87.

${ }^{6}$ Аганезов С.С., Аганезова Н.В. Возможности снижения риска преждевременных родов с позиции доказательной медицины. Акушерство и гинекология. 2015. № 4. C. $62-68$. 
клінічно виражених форм внутрішньоутробних інфекцій становить 4-16\% за передчасних пологів. Характер та важкість інфекційного процесу у плода визначається стадією його внутрішньоутробного розвитку в момент інфікування. У першому триместрі внутрішньоутробне інфікування може призвести до формування вроджених уражень розвитку плода, в другому та третьому - до гідроцефалії, гідронефрозу, затримки росту, дистресу плода. За інфікування в пологах темпи розвитку інфекційного процесу залежать від інтенсивності колонізації та ступеня зрілості плода ${ }^{7,8,9}$.

Розвиток ІЗУП, як правило, щільно пов'язаний зі станом імунологічного статусу вагітних. Відомо, що під час гестаційного періоду виникає фізіологічний імунодефіцит, на тлі якого підвищується ризик появи інфекційно-запальних захворювань як у матері, так і у плода та новонародженого.

Імунологічні причини інфекційних ускладнень вагітності зумовлені зростаючим рівнем $\gamma$-інтерферону в сироватці крові, що порушує процес плацентації, інвазію трофобласта й токсично впливає безпосередньо на ембріон. Також відзначається високий рівень прозапальних цитокінів (IL-1 $\beta$, IL-6, IL-8, TNF- $\alpha$ ) у крові, що призводить до порушень розвитку хоріону та відторгненню плідного яйця. Визначено, що деякі генотипи цитокінів (IL-6, TNF- $\alpha$, VEGFA) $є$ асоційованими з акушерськими ускладненнями прееклампсією, затримкою росту плода, передчасними пологами, сепсисом, однак отримані дані є досить суперечливими.

Сучасними особливостями інфекційно-запальних захворювань статевих органів $€$ перевага полімікробних асоціацій, де мікроорганізми діють у вигляді симбіозу, і схильність до торпідного перебігу, що пов'язано з низькою реактивністю макроорганізму. Неефективність лікування часто пов'язана із запізнілим наданням лікувальної допомоги, низькою комплаєнтністю деяких медикаментів, відсутністю бажання пацієнток своєчасно лікуватися. Дотепер потребують вирішення питання діагностики, лікування

7 Александрова Н.В., Баев О.Р. Ранние этапы становления системы матьплацента-плод. Акушерство и гинекология. 2011. № 8. С. 4-10.

${ }^{8}$ Александрова Н.В., Донников А.Е. Акушерские осложнения при беременности высокого риска. Возможности прогнозирования. Акушерство и гинекология. 2012. № 5. C. 104-108.

${ }^{9}$ Group B streptococcus immunization during pregnancy for improving outcomes. Cochrane Database of Systematic Reviews / N. Michihata et al. 2015. Jan. DOI: 10.1002/ 14651858. CD011496. Pub3. 
і профілактики ІЗУП, оскільки немає чітких критеріїв у лікувальній тактиці, не узагальнені дані про ефективність комплексної терапії.

В останні роки в літературі з'явилось багато наукових праць, в яких досліджувалась можливість використання озонотерапії та імунокорекції під час запальних захворювань придатків матки, переношування вагітності, дистресу плода. Було доведено їхню здатність стимулювати імунітет, впливати на цитокіновий статус, здійснювати детоксикаційну та антимікробну дію. Тобто йдеться про доцільність використання медичного озону й імунокоректорів у комплексному лікуванні інфекційного процесу. Озонотерапія застосовується також у лікуванні гінекологічних інфекцій, лікуванні та профілактиці затримки розвитку плода. Таким чином, проблема ІЗУП у вагітних залишається актуальною в сучасному акушерстві та потребує подальшого вивчення.

Метою дослідження стало зниження частоти перинатальної смертності і захворюваності у жінок 3 материнсько-плодовою інфекцією шляхом уточнення механізмів розвитку інфекційнозапальних уражень плода та розроблення клініко-патогенетичних підходів до їх лікування та профілактики.

Для досягнення мети було виконано такі дослідження: ретроспективний аналіз причин перинатальної захворюваності та смертності; інфекційний моніторинг вагітних 3 ІЗУП та їхніх новонароджених; обстеження вагітних 3 антенатальною загибеллю плода; обстеження вагітних 3 ІЗУП 3 вивченням інфекційного збудника, гормонів, гемостазу, імунного стану, ендотеліального статусу, процесів апоптозу, наявності оксидативного стресу; розроблення та використання сучасних методів лікування i профілактики ІЗУП узалежності від інфекційного збудника; патоморфологічне та імуногістохімічне дослідження плацент від вагітних з ІЗУП.

\section{1. Клініко-інструментальні результати обстеження вагітних з ІЗУП}

Згідно 3 результатами проведеного ретроспективного аналізу пологів, які відбулися в Харківському обласному клінічному перинатальному центрі (Харків, Україна), у 14276 жінок за період 2011-2015 pp. у структурі захворюваності доношених новонароджених частота ІЗУП дорівнювала 1,7\%-6,5\%. У структурі захворюваності недоношених новонароджених ІЗУП становило 
10-15\%. Серед причин ІЗУП переважали сечові інфекції, інфекції статевих шляхів, вірусні захворювання матері, передчасний розрив плодових оболонок.

Показники перинатальної смертності коливалися від 18,22\% до $26,56 \%$, з них випадки антенатальної загибелі плода дорівнювали $12,27-20,33 \%$, серед яких переважали недоношені (61,9\%). У 35,5\% випадків АЗП мали місце ускладнення, пов'язані з інфекційними ураженнями фетоплацентарного комплексу, запальними захворюваннями матері, що не були своєчасно діагностовані та адекватно проліковані, що $є$ резервом зниження перинатальної смертності. Малюкова смертність коливалася від 4,1\% до 11,06\%, у середньому $-7,27 \%$, 3 них неонатальна смертність у середньому становила 4,1-6,9\%. За структурою у доношених та недоношених загиблих дітей переважали внутрішньоутробні інфекції та вроджені вади розвитку плода.

Для визначення етіологічного чинника перинатальних інфекцій був проведений бактеріальний моніторинг фетоплацентарного комплексу в 1043 жінки. За результатами дослідження серед збудників ІЗУП провідну роль грала бактеріальна інфекція (69\%), вірусна $(26,6 \%)$ та кандідозна (13,9\%). Стафілококова інфекція вражала $34,8 \%$ вагітних 3 ІЗУП, стрептококова - 4,02\%, ентеробактерії - 6,04\%. Вірусна інфекція була представлена переважно ВПГ $(22,4 \%)$ та ЦМВ (20,9\%). Змішана інфекція зустрічалася в 24,4\% випадків, вона найчастіше була представлена різними типами стафілококів або стрептококів у сполученні з кандидозом (30,3\%), ЦМВ та ВПГ - (13,4\%), сполученням ентеробактерій 3 іншими збудниками $(20,1 \%)$, уреа- та мікоплазми (8,7\%). Під час порівняння результатів мікробіологічного обстеження вагітної та плода у $80,9 \%$ випадків не виявлено значних відмінностей між спектром інфекцій, вражаючих вагітну та плід.

Надалі під час обстеження 423 вагітних з ІЗУП враховувався тип інфекційного ураження (бактеріальний, вірусний, кандидозний, змішаний). Найбільш частими скаргами вагітних з ІЗУП були зуд та печія (64,8\%), неприємні відчуття при сечовиділенні (46,6\%). Серед збудників бактеріальної інфекції переважали стафілококи (73\%), ентеробактерії (35\%), стрептококи (26\%), хламідії $(24,2 \%)$, колібацилярна інфекція (19\%), клебсієла $(19 \%)$, токсоплазма $(11,1 \%)$, уреаплазма $(9,3 \%)$. У жінок з вірусними ІЗУП найбільш часто визначалися ЦМВ (70,4\%) та ВПГ (66,7\%). Змішана інфекція була 
визначена у 201 (47,5\%) вагітних основної групи, до складу якої входили від двох до чотирьох асоціацій мікроорганізмів.

Під час УЗД найчастіше за бактеріального ураження зустрічалися сегментарні скорочення матки (92\%), передчасне дозрівання плаценти (88\%), підвищення ехогеності кишечнику (69\%), гіперплазія або гіпоплазія плаценти (64\%). За вірусної патології - сегментарні скорочення матки $(62,1 \%)$, маловоддя $(68,7 \%)$, передчасне дозрівання плаценти $(41,7 \%)$. За змішаної інфекції були виявлені майже всі перераховані ознаки внутрішньоутробного інфікування. Кандидозне ураження супроводжувалося загрозою передчасних пологів (44\%), передчасним дозріванням плаценти та ЗРП. Гідроцефалія, вентрикуломегалія, інтракраніальні кальцинати, неімунна водянка плода та гепатомегалія були характерні більше для вірусного ушкодження. Багатоводдя зустрічалося переважно за бактеріального та змішаного варіантів ІЗУП. Зменшений розмір вилочкової залози плода був визначений у 71,2\% випадків у вагітних 3 ІЗУП. Під час оцінки розмірів тимусу плода торакотимічне співвідношення (TT-Ratio) в контрольній групі становило $0,44 \pm 0,04$, за бактеріального ураження - 0,39 $\pm 0,02$, за вірусного $-0,36 \pm 0,01$, за кандидозного $0,42 \pm 0,01$, за змішаного - $0,38 \pm 0,03$, що вказує на значну роль тимусу в патогенезі ІЗУП.

У 70\% вагітних з ІЗУП порушення кровотоку в системі матиплацента-плід визначалися вже в 34-35 тижнів вагітності й супроводжувалися двобічними змінами кровотоку в маткових артеріях. За бактеріального ураження порушення плодово-плацентарного, плодового та маткового кровотоку відбувалося за рахунок підвищення резистентності в артеріях пуповини та маткових артеріях. За вірусного та змішаного інфікування компенсоване порушення плодового кровотоку здійснювалося за рахунок підвищення резистентності в аорті плода, середній мозковій артерії, в обох артеріях пуповини, маткових артеріях.

Під час оцінки біофізичного профілю плода найбільш низька оцінка відзначалася за змішаного ураження плода $(8,8 \pm 0,2$ бала), за бактеріального - 9,3 $\pm 0,3$ бала, за вірусного - 9,8 $\pm 0,3$ бала, за

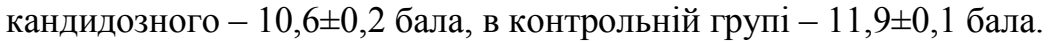

Порівняльний аналіз показників кардіотокографії плода у вагітних з ІЗУП продемонстрував порушення стану плода переважно в групах зі змішаним (38,2\%) та вірусним $(34,3 \%)$ ураженням. 
Зміст прогестерона, естріолу, плацентарного лактогену та кортизолу у вагітних з ІЗУП вірогідно відрізнявся від контрольних показників за бактеріального, вірусного та змішаного ушкодження $(\mathrm{p}<0,05)$. Зменшення показників прогестерону та підвищення естріолу під час ІЗУП призводить до передчасного розвитку пологів, підвищений рівень кортизолу вказує на роль стресового фактору за інфекційного ураження вагітної.

У вагітних з ІЗУП спостерігається підвищення таких біологічно активних речовин, як серотонін (796,5 $\pm 30,8$ нмоль/л), гістамін $(593,1 \pm 19,4$ нмоль/л), адреналін (5,2 $\pm 0,4$ нмоль/л), що може бути зумовлено активністю інфекційних агентів і зниженим імунітетом вагітних та сприяти розвитку передчасних пологів.

За бактеріального та змішаного інфікування вагітних візначалося скорочення часу рекальцифікації та зменшення АЧТЧ, підвищення D-дімеру, скорочення протромбінового та тромбінового часу, антитромбіну та плазміногену, підвищення змісту фібриногену та ПДФ, що може вказувати на наявність компенсованої форми хронічного ДВЗ-синдрому.

Вміст вітаміну D у вагітних з ІЗУП був знижений (14-21 нг/мл), особливо в разі змішаного ураження, та коливався від 14 до 21 нг/мл, дорівнюючи в середньому 18,9 $\pm 3,2$ нг/мл.

\section{2. Дослідження імунного гомеостазу у вагітних з ІЗУП}

Дослідження імунного гомеостазу показало, що в інфікованих вагітних спостерігалися різного ступеня виразності зміни в отриманих показниках. Зокрема, відзначається лейкоцитоз за бактеріального та змішаного ураження, лімфоцитопенія - за вірусної інфекції $(\mathrm{p}<0,05)$. Визначені зміни клітинного імунітету, які характеризувалися субпопуляційним дисбалансом складу Т-лімфоцитів із підвищенням імунорегуляторного індексу CD4+/CD8+. Зокрема, у вагітних з вірусними інфекціями $\mathrm{Th} / \mathrm{Ts}$ підвищено в середньому в 1,9 рази в порівнянні 3 вагітними контрольної групи. Вміст В-лімфоцитів за вірусного ураження був вище норми, причому кратність його стосовно контролю становила 1,8. За бактеріального ураження співвідношення Т-хелперів і Т-супресорів підвищено в 1,7 рази, а вміст В-лімфоцитів знижено в 1,25 рази в порівнянні 3 контрольними показниками. За бактеріального ураження спостерігається зниження активації натуральних кілерів $(10,3 \pm 1,2 \%)$ та бактерицидної активності 
нейтрофілів $(27,5 \pm 1,2 \%)$. Фагоцитарна активність вірогідно відрізнялася від контролю за бактеріального ураження $(89,3 \pm 1,8 \%$ та 3,3 $\pm 0,1$ відповідно).

Концентрація IgA в сироватці крові вірусної групи була змінена у 91,7\% вагітних. Зміни вмісту IgM зареєстровано в 78,3\% випадків, a рівня $\operatorname{IgG}$ - у 86,7\% вагітних із вірусними інфекціями. За бактеріального ураження концентрація $\operatorname{IgA}$ була змінена у $84,8 \%, \operatorname{IgM}$ - у $69,7 \%, \operatorname{IgG}$ - у 77,3\%. В інфікованих вагітних змішаної етіології було виявлено достовірне підвищення рівнів $\operatorname{IgG}(14,5 \pm 0,7$ г/л), ЦІК $(131,5 \pm 10,6$ у. од.) у порівнянні 3 цими показниками в контролі, а також незначне підвищення рівня IgM $(1,36 \pm 0,07$ г/л), що може вказувати на дисбаланс імуноглобулінів. Уміст IgA в крові хворих становив 2,3 $\pm 0,2$ г/л порівняно 3 контрольними даними $-3,5 \pm 0,3$ г/л $(\mathrm{p}<0,05)$. За кандидозного ураження виявлялися високі тітри антитіл класів $\operatorname{IgM}(1,2 \pm 0,03 г / л)$, $\operatorname{IgG}(11,8 \pm 0,9$ г/л), $\operatorname{IgA}(2,1 \pm 0,4$ г/л).

Під час вивчення локального імунітету в інфікованих вагітних визначено підвищення концентрації секреторного $\operatorname{IgA}$ ( $\operatorname{sgA})$ у 2,2 рази за бактеріального ураження, в 1,6 рази - за змішаного ураження в порівнянні 3 контролем. За вірусного ураження відзначається зниження змісту $\mathrm{sIg}$ у зв'язку з пригніченням дії вірусів на його синтез або виснаження продукції в разі високої потребі, що може вказувати на дефект місцевого захисту.

За бактеріальної інфекції цитокіновий профіль у крові вагітних характеризувався підвищенням IL-1 $\beta$ у 1,3 рази, IL-2 - у 1,6 рази і TNF- $\alpha$ - у 1,8 рази в порівнянні 3 контрольними показниками. Цитокіновий профіль крові вагітних за вірусного ураження характеризувався підвищенням IL-1 $\beta$ (у 1,7 рази), IL-2 (у 1,9 рази) i TNF- $\alpha$ (у 1,8 рази), за грибкового ураження привертало увагу

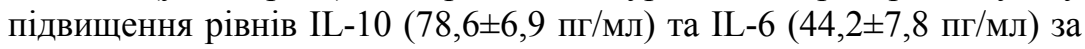
незмінних рівнів TNF- $\alpha$ та IL-1 $\beta$ ( $<0,05)$. Під час дослідження цитокінового статусу звертає на себе увагу незначне підвищення вмісту IL-1 $\beta$ в крові в разі інфікування статевих шляхів грибами кандида у вагітних $(10,5 \pm 1,3$ пг/мл), підвищення вмісту

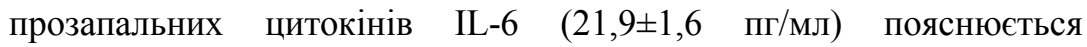
системними реакціями, які сприяють локалізації інфекції, але не захищають слизові оболонки. Особливо необхідно підкреслити зниження змісту цитокінів IL-10 (39,8 $\pm 6,9$ пг/мл), дефіцит яких $€$ однією 3 причин активації запальних процесів i переходу їх 
у хронічну форму. У вагітних 3 кандидозним ураженням показник

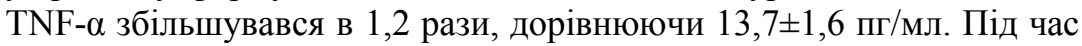
аналізу цитокінового статусу крові вагітних за змішаного ураження привертає увагу підвищення вмісту IL-1 $\beta$ у сироватці крові в 5,7 разів $(56,3 \pm 1,7$ пг/мл) і збільшення вмісту прозапальних цитокінів IL-6 майже вдвічі $(37,8 \pm 3,5$ пг/мл). Крім того, відзначається зниження рівня протизапальних цитокінів IL-4

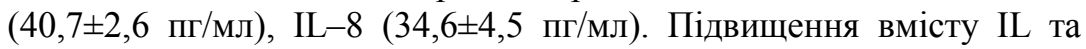
TNF- $\alpha$ в крові вагітної в разі ІЗУП сприяє запуску продукції прозапальних цитокінів у фетоплацентарному комплексі, що призводить до змін концентрації цитокінів у тканинах плаценти та пригнічення клітинної ланки імунітету в плодів та новонароджених. Збільшення концентрації IL-6 в крові вагітних пояснюється надлишковою активацією симпатоадреналової системи.

Більш виразні зміни концентрації цитокінів відзначалися в амніотичній рідині у вагітних 3 ІЗУП, які продемонстрували підвищення IL-1 $\beta$ за бактеріального ураження у 2,7 рази, за вірусного - у 3,5 рази, за змішаного - у 4,6 рази. Значення IL-6 також були підвищені відповідно у 2,3 рази за бактеріальної інфекції, в 3,6 - за вірусної, в 1,7 - за кандидозної та в 3,9 рази за змішаного ураження. IL-8 збільшувався тільки за вірусної у 1,9 рази та за змішаної - у 2,1 рази. TNF- $\alpha$ також значно підвищувався за вірусної - у 2,2 рази, за змішаної - у 4,7 рази.

Підвищений рівень IL-1 $\beta$ та TNF- $\alpha$ в пуповинній крові за всіх типів ІЗУП віддзеркалює ступінь антигенного навантаження, що може призводити до збільшення проникливості гематоенцефалічного бар'єру та відігравати важливу роль у патогенезі перинатального ураження ЦНС новонародженого, особливо за вірусної та змішаної форм ІЗУП. Збільшення вмісту IL-1 $\beta$ та IL-8 в пуповинній крові під час ІЗУП супроводжується напругою клітинного та гуморального імунітету, який призводить до виснаження його резервів та спричиняє лейкоцитарну депресію.

Підвищення рівня цитокінів можна розглядати як фактор пошкодження ендотелію судин. Під час вивчення ендотеліального статусу найбільші зсуви змісту ЕТ-1 спостерігаються у вагітних зі змішаним $(19,7 \pm 2,8$ нг/мл) та бактеріальним $(16,5 \pm 2,3$ нг/мл) ураженням вагітної та плода, вірусне ураження також вірогідно змінювало показники ЕТ-1 $(11,8 \pm 1,9$ нг/мл), кандидоз майже не впливав на показники ET-1 у порівнянні з контрольною групою 


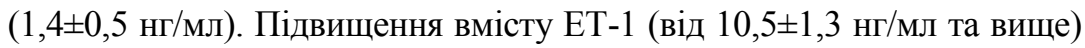
сприяло розвитку вазоспазму, тромбоутворення, проліферативних процесів, які призводять до гіпоксії та ішемії міоцитів міометрія, плацентарної дисфункції, дистресу плода, передчасних пологів.

Під час вивчення концентрації цГМФ у сироватці крові було визначено його підвищення за ІЗУП $(9,1 \pm 1,3$ нмоль/л) у порівнянні 3 контрольними показниками $(4,8 \pm 0,9$ нмоль/л). Найбільше виражені зміни цГМФ за вірусного (13,1 $\pm 1,8$ нмоль/л), бактеріального $(11,3 \pm 1,2$ нмоль/л), змішаного (12,9 $\pm 1,5$ нмоль/л), кандидозного ураження (6,2 $\pm 0,7$ нмоль/л).

Вивчення показників нитратів та нитритів продемонструвало зниження їх кількості у вагітних з ІЗУП у порівнянні з неінфікованими вагітними, що вказує на розлади локальної гемодинаміки, порушення функції судинного русла та наявність вазоспазму. Найбільші відмінності були визначені за бактеріального ураження $(17,5 \pm 1,9$ мкмоль/л), вірусне та змішане інфікування також мали негативний вплив на зміст нитратів та нітритів $(\mathrm{p}<0,05)$.

Під час вивчення вмісту VEGF у вагітних з ІЗУП були отримані такі результати: в інфікованих вагітних рівень VEGF коливався від 258,2 до 411,7 пг/мл, дорівнюючи в середньому 326,5 355,3 пг/мл. Під час подальшого дослідження було виявлено, що концентрація VEGF змінювалася в залежності від типу збудника, особливо за змішаної інфекції.

За інфекційного ураження визначалося посилення процесів апоптозу, що проявляється підвищенням рівня sFAS-ліганду в сироватці крові, особливо за вірусного $(4,2 \pm 0,7$ нг/мл) та змішаного $(5,1 \pm 0,9$ нг/мл) ураження вагітної та плоду.

Під час аналізу окислювально-антиоксидантного гомеостазу у вагітних з бактеріальним ураженням виявлена активація ПОЛ

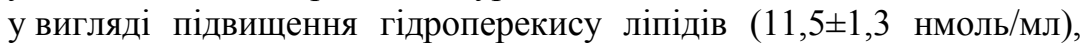
активності церулоплазміну $(2,56 \pm 0,159$ нмоль/мл) та глутатіонпероксидазної активності $(159,43 \pm 19,4$ нмоль/мл), зниження

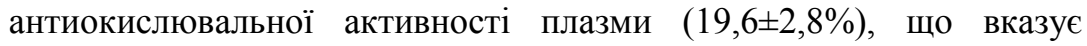
на напруження антиоксидантних систем організму.

За вірусного ураження вміст гідроперекису ліпідів підвищився майже в 6 разів, виявлено значне зменшення антиокислювальної активності плазми $(16,3 \pm 2,4 \%)$ і реактивна активація глутатіонпероксидази $(177,1 \pm 7,9$ нмоль/мл) та ферментативно активного церулоплазміну. Ці зміни свідчать про протидію організму 
пошкодженням, що спричиняє збудник, які реалізуються через активацію антиоксидантних систем, але не є достатніми.

Кандидозне ураження вагітних також мало вплив на систему ПОЛ/АОС, але меншого ступеня 3 вірогідним підвищенням гідроперекису ліпідів у 2,5 рази $(6,3 \pm 0,9$ нмоль/мл) та зниження антиоксидантної активності у 1,8 рази $(33,2 \pm 3,4 \%)$.

У вагітних 3 інфікуванням змішаної етіології визначено підвищення гідроперекису ліпідів у 5,1 разів та зниження загальної антиокислювальної активності плазми (з 58,3 $\pm 4,2$ до 16,7 $2,1 \%$ ), підвищення активності церулоплазміну $(2,37 \pm 0,15$ нмоль/мл)

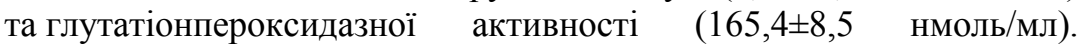
Це свідчить про підвищений вміст вільних радикалів у плазмі, які можуть завдавати пошкоджуючого впливу в системі матиплацента-плід та призводити до дистрофічних явищ у плаценті, ЗРП та дистресу плода.

Таким чином, ІЗУП супроводжується порушеннями різних ланок імунітету, сприяє розвитку дисфункції ендотелію, оксидативному стресу, змінам процесів апоптозу, ступінь тяжкості яких залежить від типу інфікування.

\section{3. Вплив ІЗУП на антенатальну загибель плода}

Враховуючи вплив інфекційних факторів на виникнення АЗП, нами було обстежено 50 вагітних 3 антенатальною загибеллю плода в терміни з 23-х до 37-ми тижнів вагітності, в яких були виключені інші ушкоджуючі фактори, крім інфекційних. Серед ускладнень теперішньої вагітності у вагітних з АЗП відмічалися загроза переривання вагітності (96\%), плацентарна дисфункція (84\%), ГРЗ із підвищенням температури (54\%), ЗРП (36\%), безсимптомна бактеріурія (32\%), гестаційний пієлонефрит (28\%), прееклампсія (18\%), анемія (12\%). Необхідно відзначити, що 68\% вагітних з АЗП мали кольпіти бактеріального або кандидозного походження, хламідіоз виявлено у $14 \%$ вагітних, уреаплазмоз - у 22\%, мікоплазмоз - у 28\%, герпетична інфекція - у 16\%, трихомоніаз у $10 \%$. Привертає увагу, що $22 \%$ вагітних мали переважно бактеріальну інфекцію, 32\% - вірусну, 10\% - грибкову, 36\% змішану. Вивчення гормонів сироватки крові у жінок з АЗП виявило виразну недостатність гормональної функції плаценти при АЗП, що може бути інформативним критерісм загибелі плода та сприяти затримці його в матці. Визначено, що у 90\% жінок з АЗП мали 


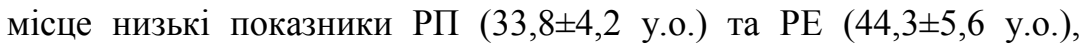
що вказувало на виразну недостатність рецепторної активності у вагітних з ІЗУП.

Під час вивчення лімфоцитарних субпопуляцій відзначалося достовірне зниження вмісту CD3+ та CD4+ у сироватці крові в порівнянні зі здоровими вагітними, що свідчить про наявність імунодефіциту, характерного для хронічних запальних процесів. Одночасно у вагітних визначено високий вміст натуральних кілерів. Концентрація NK-клітин у жінок 3 АЗП становила 26,3 $\pm 1,8 \%$ у порівнянні з контролем (18,8 $\pm 1,5 \%)$, тобто вище в 1,5 раза. Ці дані $\epsilon$ прогностично несприятливими для перебігу вагітності, оскільки натуральні кілери провокують цитотоксичні реакції.

Окрім безпосередньої пошкоджувальної дії на плід, натуральні кілери синтезують прозапальні цитокіни, в тому числі TNF- $\alpha$. У жінок $з$ наявністю АЗП визначено підвищення вмісту TNF- $\alpha$ $(42,3 \pm 4,8$ нг/мл). Отримані результати вказують на той факт, що АЗП може бути пов'язана не тільки з прямою пошкоджувальною дією інфекційного агенту на плід, а й $з$ неадекватним розвитком імунних реакцій у матково-плацентарному комплексі. Привертає увагу підвищення рівня sFasL майже в 30 разів, що вказує на посилення процесів апоптозу при АЗП.

Дослідження ендотеліального статусу у вагітних 3 АЗП продемонструвало напруження в роботі цієї системи, що проявлялося підвищенням змісту судино-ендотеліального фактору росту та ендотеліну-1. Привертають увагу зміни в системі ПОЛ та АОС у вагітних з АЗП, зокрема: підвищення вмісту гідроперекису ліпіду в 6,2 разів, ферментативно-активного церулоплазміну та ендотоксину - майже вдвічі, глутатіонпероксидазної активності у 1,5 раза, що вказує на напруження системи та розвиток оксидативного стресу.

У загиблих плодів були визначені двобічна пневмонія (72\%), менінгоенцефаліт (64\%), некротичний гепатіт (44\%), інфільтративний міокардіт (36\%). У тимусі плоду визначалася акцидентальна трансформація, яка проявлялася зменшенням його маси та об'єму

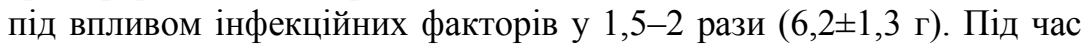
патоморфологічного дослідження у 84\% випадків були присутні ознаки неспецифічного продуктивного запалення в децидуальній оболонці з ушкодженням матково-плацентарних артерій. Отримані дані свідчать про наявність процесів декомпенсації в плацентах, 
зумовлених переважно інфекційним фактором, що пояснює патогенез перинатальних втрат.

Для визначення морфофункціональних змін у плаценті в залежності від типу інфікування було проведено вивчення морфологічних та імуногістохімічних особливостей будови плаценти у 40 породіль з ІЗУП різного типу інфікування. У всіх досліджуваних групах були знайдені гістологічні ознаки неоднородної зрілості ворсинчастого дерева, такі як наявність проміжкових диференційованих ворсин та наявність склерозованих ворсин, зниження функціональної активності епітеліальних структур. Як прояви репаративних процесів у відповідь на наявність інфекції була зафіксована компенсаторна гіперплазія капилярів або компенсаторний ангіоматоз ворсин. За наявності інфекційного ураження спостерігалось зниження щільності базального прошарку епітелію, що виявлялося у вигляді слабкого специфічного забарвлення i звуження зони позитивної реакції з МКАТ до колагену IV типу за значного збільшення його змісту в стромі ворсин.

У зонах накопичення фибриноїда, особливо за вірусної інфекції, виявлялися значні нерівномірні відкладання колагену IV типу, що також вказує про порушення тинкторіальних властивостей цих структур під час вагітності, ускладненої ІЗУП. За вірусної та змішаної інфекціях визначена помірна експресія ММР-9 лише в поодиноких клітинах Кащенко-Гофбауера термінальних ворсин та значне зниження експресії у трофобласті й сполученій тканині термінальних ворсин, що можна розцінювати як порушення компенсаторних реакцій, спрямованих на поліпшення обмінних процесів між матір'ю і плодом.

За порівняння ступеня експресії колагену IV типу і MMP-9 відзначалася зворотно пропорціональна залежність: чим вище був рівень експресії колагену, тим нижчим був рівень експресії металопротеїнази, що свідчить про перевагу склеротичних процесів у екстрацелюлярному матриксі проміжних і термінальних ворсин. Ендотеліоцити інтимі судин та капілярів ворсин у більшості випадків були приплющені, будова клітинних стиків була порушена через деструкцію та набряк. У частині судин було виявлено відшарування ендотеліоцитів у просвіт судини та порушення їхньої стінки, крім того, спостерігались виразна десквамація й огнищеві некрози ендотелію. 
Крім цього, в усіх групах спостерігалися різні стадії вступу клітин до апоптозного стану. Апоптотичні зміни на нашому матеріалі супроводжувалися дрібноглибчастим розпадом ядер клітин, фрагментацією клітинного змісту на окремі апоптотичні тільця. В ультраструктурі інших клітин відзначалася поява пікнотичних ядер, ядер 3 каріорексісом та каріолізисом, різко вираженим мікроплазматозом. При цьому якщо в цитоплазмі епітеліальних клітин ворсин експресію маркеру bcl-2 можна було оцінити як помірну (++), в інтимі їхніх судин, ендотеліоцитах капилярів вона була негативною (-), що розцінювалося нами як прояв оксидативного стресу і нездатності до відтворення цілісності ендотеліального пласту.

Рівень експресії VEGF у плацентах групи вагітних 3 ІЗУП демонстрував східну з bcl-2 картину: фактор росту ендотелію або не виявлявся зовсім, або показував слабку $(+)$ та в поодиноких випадках помірну (++) імунну реакцію. Імунонегативними виявились не тільки всі клітини - продуценти цього судинного фактору, але й ендотелій капілярів ворсин. У групі контролю трансформуючий фактор росту TGF- $\beta$ виявлений у синцитіотрофобласті, епітелії ворсин, у позаворсинчастих субпопуляціях цитотрофобласту, де його експресія була виразною (+++). У групах вагітних з ІЗУП кількість TGF- $\beta$ була знижена до помірної $(++)$ та слабкої $(+)$ нерівномірної реакції. Таким чином, материнсько-плодова інфекція впливає на стан плацентарного комплексу, викликаючи зміни в ендотеліальній системі, системі апоптозу, факторів росту, що важливо для розроблення диференційованого підходу до лікування і профілактики інфекційнозапальних уражень плоду.

\section{4. Сучасні підходи до лікування ІЗУП}

Для уточнення особливостей патогенезу, розроблення та апробації сучасних методів лікування ІЗУП було створено експериментальну модель ІЗУП, для чого використовували 104 самиці щурів лінії Вістар віком 6 місяців та 326 їхніх плодів, яким було зроблено моделювання бактеріальної, вірусної, кандидозної інфекції та проведено лікування з використанням імунокоректорів.

Після моделювання інфекційного процесу загальні зміни були більш виражені у тварин з бактеріальною та вірусною інфекцією, ніж 3 кандидозною. Найбільш виразні зміни вмісту лейкоцитів, фагоцитарного індексу спостерігалися за бактеріального та канди- 
дозного ураження. За вірусного ураження відзначалося зменшення РБТЛ та підвищення згортання крові. Під час подальшого дослідження спостерігалася гіпотрофія плодів, крововиливи у внутрішні органи плодів, плаценти до 17,7\% за грибкової інфекції та до 33,3\% за бактеріальної. Монотерапія грибкової інфекції нивілюється впливом інфекційного агента на плід, але залишаються патологічні зміни в плаценті, що можна розцінювати як субкомпенсацію.

Лікування бактеріальної, вірусної та мікотичної інфекцій потребує обов'язкового призначення імуномодуляторів для досягнення репродуктивних показників, порівняних 3 контролем. Дія імуномодулятора реалізується насамперед через активацію процесу фагоцитозу; активація лімфоцитів спостерігається лише за вираженої бактеріальної інфекції. Морфологічні зміни проявляються за рахунок зниження геморагічних явищ у плаценті та у плода, зниження явищ гіпотрофії плода до показників інтактних тварин.

Вивчення процесів осифікації плодів у тварин 3 експериментальним інфекційним процесом дозволяє стверджувати, що в разі інфекції спостерігається неспецифічне зниження осифікації, яке залежить від важкості інфекційного процесу та здатне призвести до затримки розвитку плода. Під час бактеріального та вірусного процесів ці зміни є більш вираженими, ніж під час грибкового, i потребують не тільки специфічної терапії, а й комплексних засобів із включенням до схем лікування імуномодуляторів.

Для вивчення змін на рівні організмів вагітної та плода, які відбуваються під впливом інфекційного процесу, для визначення ефективності наданої терапії 423 обстежувані вагітні жінки були розподілені по клінічних групах у залежності від типу інфекційного збудника. Перша група з бактеріальним ураженням (100 вагітних), друга група - 3 переважно вірусною патологією (108 вагітних), третя група - 3 кандидозним ураженням (100 вагітних), четверта група - зі змішаною інфекцією (115 вагітних). Контрольна група включала 30 практично здорових вагітних жінок, які народили здорових немовлят. Групи відповідно до чинників, часу виникнення інфекції, репродуктивного анамнезу, соціального статусу були репрезентативними. Кожна із клінічних груп була поділена на три підгрупи в залежності від методу лікування: традиційне лікування отримали 120 вагітних, комплексне 3 використанням імунокоректорів - 129 вагітних та 174 - 3 імунокорекцією та додатковим використанням медичного озону. 
У групі вагітних з бактеріальним ураженням після проведеної комплексної терапії засіювання статевих шляхів бактеріями визначено у 15 (10\%) вагітних на відміну від результатів традиційного лікування - 46 (30,7\%). Показники імунограм майже не змінювалися після традиційної терапії, після комплексного лікування зникали ознаки імунологічних розладів та цитокінової дисфункції. Під час аналізу імунного статусу після проведеної комплексної терапії вірогідно змінювався рівень Т-хелперів (СД4+), Т-супрессоров (СД8+), вміст NK-клітин. У гуморальній ланці імунітету було визначено нормалізацію $\operatorname{IgG}$ та $\operatorname{IgA}$, які сягали контрольних значень. Цитокіновий профіль у вагітних після комплексного лікування характеризувався зниженням прозапальних цитокінів IL-1 $\beta$, IL-6 та TNF- $\alpha$, вірогідно відрізняючись від показників жінок, що отримували традиційну терапію $(\mathrm{P}<0,05)$.

Найбільш виразні зміни ПОЛ/АОС відмічалися після проведеного комплексного лікування в порівнянні з традиційною терапією $(\mathrm{p}<0,05)$.

Під час аналізу гормонального профілю в залежності від методу лікування було визначено підвищення прогестерону та зниження кортизолу у 87,5\% вагітних після імунокорекції та озонотерапії і тільки у 33,3\% вагітних - після традиційного лікування.

Лікування з використанням імунокоректору та медичного озону сприяє усуненню інфекційних факторів - результати бактеріоскопічного обстеження піхви після лікування наближалися до показників контрольної групи. Також у 69,4\% відзначалося зникнення ультразвукових ознак материнсько-плодової інфекції, тоді як за традиційного лікування - тільки в 33,3\% вагітних (p<0,05).

УЗД тимусу плода виявило, що після проведеної традиційної терапії тимус сягав нормальних розмірів у 26,7\%, після імунокорекції - у 53,3\%, після комплексної - у 85\% вагітних $(\mathrm{p}<0,05)$.

Аналіз подальшого перебігу вагітності й пологів жінок обстежених груп продемонстрували, що в результаті проведення запропонованої корекції вдалося знизити частоту інфекційних ускладнень в основній групі до $5,6 \%$ проти $16,7 \%$ у групі 3 традиційним лікуванням $(\mathrm{p}<0,05)$.

Пологова діяльність розпочалася спонтанно у всіх спостереженнях, передчасні пологи у 2,3 рази частіше спостерігалися після традиційного лікування, ніж після комплексного $(\mathrm{p}<0,05)$. 
Під час аналізу стану новонароджених за шкалою Апгар украй низьку оцінку мали 7 дітей, в яких було визначено СДР, що зумовлено передчасними пологами та потребувало проведення ШВЛ. Серед інших новонароджених оцінку 7-10 балів в основній групі отримали 35 (97,2\%) дітей, що було значно вищим, ніж після традиційного лікування - 22 (73,3\%).

В аналізі маси тіла новонароджених було виявлено, що в основній групі (комплексне лікування) 3 масою більше 3000 г народилося 32 (88,9\%) дітей, що вище, ніж у групі порівняння (традиційна терапія) - $20(66,7 \%)(\mathrm{p}<0,05)$.

Серед захворювань новонароджених були визначені ураження ЦНС $(31,8 \%)$, РДС $(51,5 \%)$, жовтяниця $(45,5 \%)$, ВУІ $(18,2 \%)$, ЗРП (10,6\%). Гнійний омфаліт визначено в одної дитини, гнійний кон'юнктивіт - у 2-х, вроджена пневмонія - у 7-ми. Під час бактеріологічного обстеження новонароджених виявлено Staphylococcus epidermidis - 20 випадків, Enterobacter aerogenus - 4, Streptococcus faecalis -2 .

Під час проведення гістологічного дослідження плаценти ознаки плацентарної дисфункції визначено у 50\%, бактеріального ураження (ексудативний вілузит, гнійний хоріоамніоніт) - у 66,7\%, переважно після традиційного лікування.

У результаті проведених досліджень у 108-ми вагітних із вірусним інфікуванням було виявлено, що через 2 тижні від початку комплексного лікування 3 використанням медичного озону в сполученні 3 імунокоректором позитивно змінювались імунологічні показники у жінок основної групи: нормалізувався рівень Т-хелперів (СД4+), Т-супресорів (СД8+), зміст IgG и IgA. У гуморальній ланці імунітету після імунокорекції 3 озонотерапією було визначено нормалізацію $\operatorname{IgG}$ та IgA, які сягали контрольних значень.

Заслуговує на увагу різке зниження $\operatorname{sigA}(109,3 \pm 11,7$ мг/л) за вірусних уражень, який здійснює захисну функцію слизових оболонок від вірусів $(\mathrm{p}<0,05)$. Використання імунокоректорів самостійно або в сполученні 3 озонотерапією нормалізує цей показник.

Цитокіновий профіль у вагітних після комплексної терапії характеризувався зниженням прозапальних цитокінів IL-1 $\beta$, IL-6 та TNF- $\alpha$, вірогідно відрізняючись від показників жінок, що отримували традиційну терапію $(\mathrm{p}<0,05)$. 
Гормональні зміни після використання озонотерапії та імунокорекції свідчили на їхню користь: підвищувався вміст прогестерону $(165,1 \pm 15,2$ нг/мл) і знижувався вміст естріолу $(24,3 \pm 2,8$ нг/мЛ $)(\mathrm{p}<0,05)$.

Імунокорекція 3 озонотерапією також впливала на вміст деяких БАР, зокрема, відзначалося зменшення рівня гістаміну та серотоніну (576,8 $\pm 23,6$ нмоль/л та 408,2 12,4 нмоль/л відповідно) в порівнянні $з$ традиційним лікуванням.

Після комплексного лікування відзначалася нормалізація показників гемостазу у 87,5\% вагітних, після традиційного - у 66,7\%.

Після використання імунокоректорів визначено значне зниження

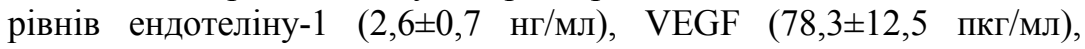
підвищення змісту вазодилятаторів, що сприяло нормалізації функції судин, профілактиці вазоспазму та відновленню локальної гемодинаміки.

Патологічний апоптоз імунокомпетентних клітин, виявлений за вірусних ІЗУП, є одним із механізмів формування імунного дефекту. Використання імунокорекції та озону сприяло компенсаторним змінам sFAS.

Привертало увагу, що найбільший вплив на показники ПОЛ/АОС здійснювала імунокорекція та озонотерапія, найменший- традиційне лікування.

Після комплексного лікування з використанням імунокоректору та медичного озону доплерометричні показники свідчили про посилення кровотока в артерії пуповини й маткових артеріях (достовірне зниження СДВ й IP). Кількість вагітних, в яких покращився материнсько-плодовий кровообіг під впливом імунокорекції та озонотерапії, зросла в 1,4 рази, що вказує на його опосередкований вплив на гемодинамічні показники фетоплацентарного комплексу. У результаті проведеного комплексного лікування в $77 \%$ відзначалося зникнення ультразвукових ознак материнсько-плодової інфекції, тоді як за традиційного лікування - тільки у 26,7\% вагітних.

За даними УЗД проведення комплексної терапії дозволило виявити нормалізацію розмірів тимусу у 87,5\% випадків.

Дані КТГ продемонстрували позитивний вплив імунокоректорів та озонотерапії на стан плоду, зменшивши кількість дітей з виразними та помірними порушеннями стану з 34,3\% до 9,3\%.

БФП плода за вірусної інфекції був знижений ( $9,8 \pm 0,3$ балів), після комплексної терапії його значення дорівнювало 11,5 $\pm 0,2$ балам, 
що перевищувало показники БФП після традиційного лікування (10,8 80,5 балів).

Аналіз перебігу вагітностей в основній групі показав, що в жінок, які отримували традиційне лікування, спостерігалися загроза невиношування вагітності - у 19 (63,2\%), плацентарна недостатність - у 14 (46,6\%), затримка росту плода - у 10 (33,3\%), передчасні пологи - у $7(23,4 \%)$. У другій клінічній групі ці показники становили відповідно - 10 (33,3\%), 8 (26,7\%), 5 (16,6\%) та 2 (6,7\%), що вказує на високу ефективність запропонованої терапії імунокоректорами. У третій групі отримані такі результати: частота загрози невиношування - у 5-ти $(10,4 \%)$ жінок, плацентарна недостатність - у 7-ми (14,6\%), ЗРП - у 3-х (6,25\%), передчасні пологи - не відзначено. Таким чином, застосування запропонованого лікувального комплексу для попередження ускладнень вагітності у жінок 3 вірусними інфекціями значно покращує ефективність лікування, що підтверджується подальшим перебігом вагітності та своєчасним народженням здорових немовлят.

Оцінюючи стан новонароджених, було виявлено, що в групі після отримання імунокорекції в комплексі 3 озонотерапією в задовільному стані народилось $47(95,8 \%)$ дітей, у групі з імунокорекцією - 27 (90\%) на відміну від групи з традиційним лікуванням, в якій найчастіше спостерігалась асфіксія новонароджених (23,3\%) та ЗРП (33,3\%).

Під час подальшого обстеження новонароджених було визначено відсутність вірусних уражень у 95,8\% новонароджених, матері яких отримували комплексне лікування, у 90\% - після імунокорекції та у 76,6\% - після традиційної терапії.

Під час дослідження результатів лікування 100 вагітних із грибковим ураженням після проведеної імунокорекції Candida albicans виявлена у 10\% вагітних на відміну від результатів традиційної терапії - 33,3\%, після проведеної місцевої озонотерапії 3 імунокоректором - у 2,5\% вагітних. Ефективність використання імунокоректорів 3 медичним озоном також підтверджується результатами бактеріоскопічного дослідження: другий ступінь чистоти піхви у 14-ти $(46,7 \%)$ після традиційного лікування, у 21-ї (70\%) - після додаткової імунокорекції і 38-ми (95\%) - після комплексної озонотерапії 3 імунокоректором; третій ступінь чистоти - у 16-ти (53,3\%), 9-ти (30\%) та 2-х (5\%) відповідно до методу лікування. 
Одразу після проведеного комплексного лікування 3 використанням імунокорекції та озонотерапії кількість лімфоцитів підвищилась на 28\%, Т-лімфоцитів - на 32\%, Т-хелперів - на $35 \%(\mathrm{p}<0,05)$. Також було відзначено зміни числа Т-супресорів та NK-клітин на 22\% и 18\% відповідно в порівнянні з періодом до початку лікування, що викликало підвищення IPI в порівнянні 3 початковими даними на $29 \%(\mathrm{p}<0,05)$.

Під час аналізу змін гуморального імунітету після комплексного лікування відбулася нормалізація $\operatorname{IgA}(1,85 \pm 0,15$ г/л), $\operatorname{IgM}$ $(1,07 \pm 0,2$ г/л) та вмісту sIg A $(0,183 \pm 0,017$ г/л), що характеризувало підвищення локального імунітету.

Після проведення комплексної терапії нормалізувалися показники протизапальних цитокінів IL-4 та IL-10, відмічалося вірогідне зменшення прозапальних цитокінів IL-1 $\beta$ (8,98 1,82 пг/мл) та TNF- $\alpha$ $(33,2 \pm 2,4$ пг/мл), що вказувало на ефективну дію імунокоректорів та озону на запальний процес.

Під час порівняння клінічних груп було визначено, що після застосування комплексної терапії рівень гідроперекису ліпідів зменшився в 3,2 рази, також спостерігалося підвищення АОА до $56,4 \pm 2,1 \%$, що сприяло нормалізації окислювально-антиоксидантного балансу та зниженню кількості ускладнень перебігу вагітності. Під час аналізу мітохондріальної активності було визначено зниження вмісту гліцерол-3-фосфату (на 31,3\%) на відміну від групи, де були застосовані озонотерапія та імунокорекція, в якій цей показник був зменшений на 9,6\% i вірогідно не відрізнявся від контрольних параметрів.

Під час аналізу гормонального профілю в залежності від методу лікування було визначено підвищення прогестерону та зниження кортизолу в 33-x (82,5\%) після імунокорекції та озонотерапії i тільки у 14-ти (46,7\%) вагітних - після традиційного лікування.

3 використанням традиційної терапії ендотеліальна дисфункція збереглась у 32-х (71\%) вагітних, за проведення імунокорекції та озонотерапії - у 17-ти $(37,8 \%)$.

Після проведеного комплексного лікування поліпшувався стан плода за даними КТГ. Спостерігалася повна нормалізація показників КТГ за легких та помірних порушень, на відміну від традиційної терапії, за якої ефект спостерігався тільки у вагітних з легкими порушеннями. Запропонована терапія вірогідно покращила показники БФП, підвищуючи середній бал оцінки стану плода майже на 20\%. 
У результаті проведеного комплексного лікування у 90\% відзначалася нормалізація кровообігу у фетоплацентарній системі за даними доплерометрії, тоді як за традиційної терапії - тільки у 45\%.

УЗД тимусу плода виявило зменшення його розмірів на $24 \%$, а використання комплексного лікування сприяло нормалізації його розмірів до терміну пологів.

Перебіг вагітності у жінок 3 кандидозною інфекцією, що отримали традиційну терапію, супроводжувався надалі загрозою переривання вагітності $(76,7 \%)$, плацентарною дисфункцією $(56,7 \%)$, ЗРП (23,3\%), ПРПО (36,7\%), передчасними пологами $(16,7 \%)$, що мало негативний вплив на перинатальні показники та вихід пологів.

Після імунотерапії загроза невиношування зберігалася у 53,3\%, плацентарна дисфункція - у 33,3\%, ЗРП - у 16,7\%, ПРПО - у 20\%, передчасні пологи - у 13,3\%. Інфіковані вагітні, які отримали комплексну імуно- та озонотерапію, відзначали загрозу недоношування у $25 \%$ випадків, плацентарну дисфункцію - у 22,5\%, ЗРП у $12,5 \%$, ПРПО - у 15\%, передчасні пологи - у $10 \%$ випадків.

Аналіз частоти перинатальних захворювань у дітей жінок, які мали вагінальну кандидозну інфекцію, показав високу частоту внутрішньоутробного інфікування (25\%) з превалюванням внутрішньоутробної пневмонії (18\%). Дистрес визначався у $30 \%$ новонароджених після традиційного лікування та 7,5\% після озоно- та імунотерапії.

Під час дослідження 115-ти вагітних з ІЗУП змішаної етіології під впливом комплексного лікування відбувалися динамічні позитивні зміни в Т- і В-системі та фагоцитарній ланці імунітету: достовірно підвищувався абсолютний і відносний вміст лімфоцитів у периферичній крові, відновлювався до значень норми вміст Т-загальних лімфоцитів (CD 3+) і Т-хелперів (CD 4+), індекс співвідношення Т-хелпери/Т-супресори $(\mathrm{p}<0,05)$. Також уже після закінчення лікування спостерігалося підвищення поглинальної активності нейтрофілів (ФЧ) і фагоцитарного індексу (ФІ) як по відношенню до показників вагітних, що отримували стандартне лікування, так і по відношенню до показників контрольної групи.

У вагітних, які одержували комплексне лікування, відбувалася швидка нормалізація цитокінового балансу в сироватці крові. Після проведеного традиційного лікування показники ІФН зменшилися майже вдвічі, а після комплексного - майже у 8 разів, дорівнюючи 
контрольним показникам. Рівень IL-6 знизився в 1,5 раза після традиційної терапії та майже втричі - після комплексної $(\mathrm{p}<0,05)$. Також після застосування медичного озону нормалізувалися показники IL-1 $\beta$ та TNF- $\alpha(8,98 \pm 1,82$ пг/мл та $14,2 \pm 1,8$ пг/мл відповідно $) \quad(\mathrm{p}<0,05)$. У разі застосування озонотерапії більш повною мірою нормалізується співвідношення про- та протизапальних інтерлейкінів за рахунок IL-10 та IL-6. Після проведеного комплексного лікування нормалізація протизапального IL-10 може вказувати на тенденцію до завершення інфекційного процесу, a IL-6 сповільнює синтез TNF- $\alpha$ та IL-1 $\beta$. Як результат, знижувалася кількість циркулюючих лімфоцитів, підвищувався рівень РБТЛ теж практично до контрольних значень. Під час вивчення гуморальної ланки імунітету відзначали значне зниження рівнів ЦІК та лімфоцитотоксичних антитіл після застосування комплексної терапії.

Під час порівняння клінічних груп, в яких було проведено традиційне лікування та озонотерапія, було визначено, що після застосування озону рівень гідроперекису ліпідів зменшився майже в 4 рази $(\mathrm{p}<0,05)$ і вірогідно не відрізнявся від контрольних показників $(3,12 \pm 0,96$ нмоль/л) $(\mathrm{p}<0,05)$. Озонотерапія також сприяла підвищенню $\mathrm{AOA}$ до $56,4 \pm 2,1 \% \quad(\mathrm{p}<0,05)$, сягаючи показників контрольної групи - 58,3 $\pm 3,5 \%$. Аналіз окислювальноантиоксидантного гомеостазу достовірно продемонстрував ефективність озонотерапії як природного антиоксиданту та його здатність відновлювати загальні антиокислювальні властивості плазми, а також знижувати рівні первинних продуктів ПОЛ.

Під час вивчення вмісту VEGF у вагітних з ІЗУП змішаного генезу після комплексної терапії концентрація VEGF коливалася від 39,5 пкг/мл до 69,9 пкг/мл і дорівнювала 52,3 $\pm 6,5$ пкг, вірогідно не відрізняючись від нормативних показників жінок контрольної групи $(48,4 \pm 5,1$ пкг/мл). Під час проведення лікування імунокоректором рівень ендотеліну-1 знижувався до 3,2士0,6 нг/мл, вірогідно не відрізняючись від контрольних показників.

Аналіз результатів терапії ІЗУП у вагітних наочно продемонстру-

вав, що своєчасне лікування із застосуванням імунокорекції та озонотерапії поліпшує перебіг вагітності порівняно з традиційним лікуванням. Дані про вихід вагітності продемонстрували, що в результаті проведення запропонованої корекції імуномодулятором 
вдалося знизити частоту передчасних пологів до 5,3\% проти $16,7 \%$ в групі 3 традиційним лікуванням. Під час аналізу стану новонароджених оцінку 7-10 балів за шкалою Апгар в основній групі отримали 35 (92,1\%) дітей - більше, ніж 22 (73,3\%) після традиційного лікування. Під час аналізу маси тіла новонароджених від вагітних зі змішаним ІЗУП було виявлено, що після проведення комплексної терапії з масою більше 3000 г народилося 34 (89,5\%) дитини, тобто більше, ніж у групі з традиційним лікуванням - 20 $(66,7 \%)(\mathrm{p}<0,05)$.

Клініко-патогенетичні механізми впливу імунокоректорів та озонотерапії на профілактику та лікування інфекційних ускладнень матері та плода у вагітних з ІЗУП полягають в їхніх імунокорегуючих та антимікробних властивостях, що підтверджується нормалізацією піхвового біоценозу, імунологічних, ендотеліальних, оксидативних показників. Таким чином, застосування запропонованого лікувального комплексу дозволяє покращити ефективність лікування, що підтверджується покращенням показників перинатальної захворюваності та зниженням постнатальних ускладнень як для матері, так і для плода.

\section{ВИСНОВКИ}

1. У структурі перинатальної захворюваності та смертності внутрішньоутробне інфікування плода посідає одне з перших місць, частота якого сягає $10-15 \%$. У виникненні ІЗУП вирішальну роль відіграють бактеріальна (69\%), вірусна (26,6\%), кандидозна (13,9\%) та змішана інфекції (24,4\%). Серед бактеріальних та вірусних збудників провідне місце посідають стафілококи $(34,8 \%)$, ВПГ-2 (9,1\%), ЦМВ (8,3\%), ентеробактерії (6,04\%), хламідії (5,3\%), стрептококи $(4,02 \%)$. Мікст-інфекція найчастіше представлена стафілококами та грибами кандида (30,3\%), ЦМВ та ВПГ-2 (13,4\%), ентеробактеріями з іншими збудниками $(20,1 \%)$.

2. Перебіг вагітності за ІЗУП ускладнюється загрозою передчасних пологів (72,8\%), кольпітами різної етіології $(64,8 \%)$, плацентарною дисфункцією $(57,5 \%)$, порушеннями цілісності епітелію шийки матки $(50,8 \%)$, гострими респіраторними захворюваннями $(31,2 \%)$, сечовими інфекціями $(27,4 \%)$. Під час УЗД вагітних з ІЗУП найчастіше зустрічалися сегментарні скорочення матки (92\%), передчасне дозрівання плаценти (88\%), 
підвищення ехогенності кишечника (69\%), гіперплазія плаценти (64\%), багатоводдя (45\%).

3. Патогенез ІЗУП включає комплексне порушення імунного статусу, ендотеліальну дисфункцію, оксидативний стрес, зміни гемостазу та гормональні розлади, зумовлені типом інфікування, які спричиняють передчасні пологи та перинатальну захворюваність i смертність. У загиблих дітей від вагітних 3 ІЗУП визначено двобічну пневмонію (72\%), менінгоенцефаліт (64\%), некротичний гепатит (44\%), інфільтративний міокардит (36\%). У тимусі плодів 3 ІЗУП визначалася акцидентальна трансформація, яка проявлялася зменшенням їхньої маси та об'єму під впливом інфекційних факторів у 1,5-2 рази $(6,2 \pm 1,3$ г).

4. Використання імунокоректорів у поєднанні 3 медичним озоном $є$ ефективним методом лікування, в результаті якого відбувається нормалізація імунного, гормонального, ендотеліального та оксидативного статусу вагітної з усуненням надалі ІЗУП, оптимізацією доношування вагітності, зниженням перинатальної захворюваності на $61 \%$ та смертності у 2,3 рази.

\section{АНОТАЦІЯ}

Статтю присвячено поліпшенню якості надання акушерської допомоги з метою зниження частоти перинатальної смертності та захворюваності в жінок з материнсько-плодовою інфекцією шляхом уточнення механізмів розвитку інфекційно-запальних уражень плода $\mathrm{i}$ розроблення клініко-патогенетичних підходів до їх лікування та профілактики.

Проблема інфекційно-запального ураження плода (ІЗУП), яка зумовлена високим рівнем вірусної та бактерійної захворюваності вагітних та призводить до ушкоджень плода і новонародженого, $є$ однією з провідних проблем сучасного акушерства і перинатології. За науковими даними частота внутрішньоутробного інфікування плода становить від 25 до $37 \%$ і не має тенденції до зниження. У структурі неонатальної смертності інфекційна патологія дорівнює, за даними різних авторів, 10-45\% перинатальних втрат.

Патогенез ІЗУП включає комплексне порушення імунного статусу, ендотеліальну дисфункцію, оксидативний стрес, зміни гемостазу та гормональні розлади, зумовлені типом інфікування, 
які спричиняють передчасні пологи та перинатальну захворюваність і смертність.

Комплексне лікування та профілактика ІЗУП із застосуванням імунокоректорів та медичного озону призводить до нормалізації імунного, інфекційного та ендотеліального гомеостазу, сприяє зменшенню кількості інфекційно-бактеріальних ускладнень у новонародженого, скорочує термін антибактеріальної терапії, знижує іiі негативний вплив, не має побічних ефектів, поліпшує результати лікування вагітних з ІЗУП, передчасним розривом плідних оболонок, безсимптомною бактеріурією, запобігає рецидивам сечових інфекцій, що сприяє значному зниженню кількості акушерських ускладнень та покращенню перинатальних показників.

\section{ЛІТЕРАТУРА}

1. Абрамченко В.В., Костючек Д.Ф., Хаджаева Э.Д. Гнойносептическая инфекция в акушерстве и гинекологии. СанктПетербург : Спец.Лит, 2005. 459 с.

2. Запорожан В.М., Аряєв М.Л., Добрянський Д.О. Акушерство та гінекологія: у 4 т. : національний підручник. Київ : «ВСВ «Медицина», 2013. Т. 2: Неонатологія. С. 636-735.

3. Picone S. Infection in late preterm infants / S. Picone et al. Early Hum. Dev. 2014. Vol. 90 (1). P. 71-74.

4. Анализ причин антенатальной гибели : материалы 13-го Всероссийского научного форума «Мать и дитя» 25-28 сентября 2012 г. / С.М. Насищева и др. Москва, 2012. С. 119-121.

5. Агаркова И.М. Неразвивающаяся беременность: оценка факторов риска и прогнозирование. Медицинский альманах. 2010. № 4. С. 82-87.

6. Аганезов С.С., Аганезова Н.В. Возможности снижения риска преждевременных родов с позиции доказательной медицины. Акушерство и гинекология. 2015. № 4. С. 62-68.

7. Александрова Н.В., Баев О.Р. Ранние этапы становления системы мать - плацента - плод. Акушерство и гинекология. 2011. № 8. C. 4-10.

8. Александрова Н.В., Донников А.Е. Акушерские осложнения при беременности высокого риска. Возможности прогнозирования. Акушерство и гинекология. 2012. № 5. С. 104-108. 
9. Group B streptococcus immunization during pregnancy for improving outcomes. Cochrane Database of Systematic Reviews / N. Michihata et al. 2015. Jan. DOI: 10.1002/ 14651858. CD011496. Pub3

\section{Information about the authors:}

\section{Lazurenko V. V.,}

Doctor of Medical Science, Professor, Head of the Department of Obstetrics and Gynecology № 2

Kharkiv National Medical University 4, Nauky avenue, Kharkiv, 61022, Ukraine

Pasiieshvili N. M., Doctor of Medical Science, Professor at the Department of Perinatology, Obstetrics and Gynecology Kharkiv Medical Academy of Postgraduate Education 58, Amosova str., Kharkiv, 61176, Ukraine 